\title{
Soluble CD44 Is Not Elevated in Blood Products
}

\begin{tabular}{|l|l|l|}
\hline R. & Reinhold & Munker $^{\mathrm{a}, \mathrm{b}}$ \\
\hline S. & Susanne & Classen $^{\mathrm{a}}$ \\
\hline W. & Wolfgang & Mempel $^{\mathrm{a}}$ \\
\hline
\end{tabular}

${ }^{a}$ Medizinische Klinik III der LMU, München, Deutschland; ' $U C L A$ Cedars Sinai Medical Center, Los Angeles, Calif., USA

Dr. Reinhold Munker, UCLA Cedars Sinai Medical Center, Division of Hematology/Oncology, 8700 Beverly Blvd-Davis 5019, Los Angeles, CA 90048-1804 (USA)

Blood transfusion can be immunosuppressive: this may manifest itself as enhanced graft survival after renal transplantation [1] and may be associated with an enhanced rate of infection or tumor recurrence after surgery for cancer [2]. The mechanism of immunosuppression appears to involve cellular components of blood, especially lymphocytes: for example in patients waiting for renal transplantation it was shown that blood transfusion with common HLA types or shared HLA-B and DR antigens induces tolerance to donor antigens [3]. An alternative explanation may be that immunosuppression is mediated by soluble factors in blood products [4]. Recently, the involvement of the cell surface adhesion molecule CD44 in tumor metastasis was characterized $[5,6]$. CD44 is expressed on many different cell types including hemato-poietic cells. An isoform of CD44 promotes metastasis in lymphoma cells [7] and soluble CD44 is elevated in the sera of patients with metastatic cancer [8] and untreated malignant lymphoma [9]. We speculated that soluble CD44 may be involved in the mechanism of immune suppression by blood transfusion and we therefore measured two isoforms of CD44 in blood products.

Supernatants from various blood products were obtained by centrifugation at $400 \mathrm{~g}$ and frozen immediately at $-80^{\circ} \mathrm{C}$. Serum samples from the same blood donors were obtained by clotting at room temperature, centrifugation at $200 \mathrm{~g}$ and also stored at $-80^{\circ} \mathrm{C}$. Packed red cells were prepared with standard methods and anti-coagulated with CPDA-1 at 4-6 ${ }^{\circ} \mathrm{C}$. Red cells of all ABO groups were represented and studied 4-21 days after donation. Platelet concentrates were prepared with Cobe Spectra and Baxter CS 3000 blood cell separators and Table 1. Concentration of soluble CD44 in blood products (mean \pm standard deviation, $\mathrm{ng} / \mathrm{ml}$ ) Type of blood product Concentration Concentration soluble CD44 (Std) soluble CD44 (Var)

Serum of normal

blood donors $414 \pm 96(11) 168 \pm 46(11)$

Platelet concentrates $306 \pm 61 *(6) 113+27(6)$

Packed red blood cells $115 \pm 44^{* *}(9) 37 \pm 17(6)$

Figures in parentheses represent number. $* \mathrm{p}<5 \%$; $* * \mathrm{p}<0.1 \%$.

stored at room temperature with gentle agitation. The concentration of soluble CD44 standard (Std) and CD44 variant (Var) was determined with an enzyme immunoas-say developed by Bender MedSystems, Vienna (Austria). As normal serum levels, the manufacturer indicated 443 
$\pm 125 \mathrm{ng} / \mathrm{ml}$ for CD44 Std and $170 \pm 54 \mathrm{ng} / \mathrm{ml}$ for CD44 Var molecules. For statistical analysis, Student's t test was used.

Generally low values could be found for both soluble CD44 molecules in blood products (for details see table 1). Especially red cell concentrates contained in their supernates only about one fourth of the values found in the serum samples of the donors. Samples of the platelet concentrates (as shown in table 1) were taken 2-4 h after harvesting. If the platelet concentrates were stored a further 3-5 days, the values for soluble CD44 were comparable: $307 \pm 86$ and 120 $\pm 11 \mathrm{ng} / \mathrm{ml}$ were measured (4 cases each, Std, Var, mean and standard deviation val-

\section{KARGEH}

E-Mail karger@karger.ch Fax + 41613061234 http://www.karger.ch

(C) 1996 S.KargerAG, Basel 0001-5792/96/0963-0187S10.00/0

ues). If red cell concentrates were stored for prolonged periods (54-72 days), the values for soluble CD44 were even lower (54 \pm 12 and $12 \pm 7 \mathrm{ng} / \mathrm{ml}$; Std, Var as before, 4 cases each). In whole blood stored at $4{ }^{\circ} \mathrm{C}$, the values remain comparable to serum controls [data not shown, only CD44 Std investigated].

Our data argue against a major role of soluble CD44 in immune suppression induced by blood transfusion, at least as far as can be studied in vitro in blood products. Such effects may be caused locally by contaminating leukocytes and other adhesion molecules like lymphocyte function associated antigen- 1 or cytokines like TGF- $\beta$ may be involved. Especially TGF- $\beta$ merits further study since it is secreted by platelets and several types of tumor cells and has strong immunosuppressive properties [10]. Recently, several cytokines like IL-6, IL-8, and TNF- $\alpha$ [1012] were detected in blood products and correlated for example with febrile transfusion reactions. The decreased values found for soluble CD44 in this study may be explained by local adsorption to plastic material, pro-teolysis, to some degree by dilution and uptake by receptors on blood cells. If blood from patients with metastic tumors is studied, different results may be obtained. At this moment, there is no evidence to indicate that soluble CD44 is involved in immunosuppressive effects caused by blood products.

References

de Waal LP, van Twuyver E: Blood transfusion and allograft survival. Crit Rev Immunol 1991; $10: 417-430$.

Blumberg N, Heal JM: Transfusion and host defenses against cancer recurrence and infection. Transfusion 1989;29:236-245. van Twuyver E, Mooijaart RJD, ten Berge IJM, van der Horst AR, Wilmink JM, Kast MW, Melief CJ, de Waal LP: Pretransplanta-tion blood transfusion revisited. N Engl J Med 1991;325:1210-1213.

Vliet WC, Dock NL, Davey FR: Factors in the liquid portion of stored blood inhibit the proliferative response in mixed lymphocyte cultures. Transfusion 1989;29:41-45.

East JA, Hart IR: CD44 and its role in tumor 10 progression and metastasis. Eur J Cancer 1993; 29A:1921-1922. 
Günthert U: CD44: A multitude of isoforms with diverse functions. Curr Top Microbiol 11 Immunol 1993;184:47-56.

Sy MS, Guo YJ, Stamenkovic I: Distinct effects of two isoforms on tumor growth in vivo. J Exp Med 1991;174:859-866.

Guo YJ, Liu G, Wang X, Jin D, Wu M, Ma J,

Sy MS: Potential use of soluble CD44 in serum 12 as indicator of tumor burden and metastasis in patients with gastric or colon cancer. Cancer Res 1994;54:422-426.

9 Ristamäki R, Joensuu H, Salmi M, Jalkanen S:Serum CD44 in malignant lymphoma: An association with treatment response. Blood 1994;84:238-243.

Munker R, Darsow M, Stötzer O, Kremer JP, Mezger J: Expression von TGF-ß-3 auf reakti-ven and malignen Zellen in Aszites und Pleu-raergüssen. Med Klin 1994;89:248-253. Muylle L, Joos M, Wouters E, de Bock R, Pee-tersmans ME: Increased TNF- $\alpha$, IL-1 and IL-6 levels in the plasma of stored platelet concentrates: Relationship between TNF $\alpha$ and IL-6 levels and febrile transfusion reactions. Transfusion 1993;33:195-199. Stack G, Snyder EL: Cytokine generation in stored platelet concentrates. Transfusion 1994; 34:20-25.

188

ActaHaematol 1996;96:187-188

Munker/Classen/Mempel 